Scientific paper

\title{
Initial Conditioning of Polymer Eelectrolyte Membrane Fuel Cell by Temperature and Potential Cycling
}

\author{
Dario Bezmalinović, ${ }^{1, *}$ Jagoda Radošević and Frano Barbir \\ ${ }^{1}$ Faculty of Electrical Engineering, Mechanical Engineering and Naval Architecture, \\ University of Split, Rudera Boskovica 32, 21000 Split, Croatia \\ * Corresponding author: E-mail: dbezma@fesb.hr, \\ telephone number: +38521305947
}

Received: 11-06-2014

\begin{abstract}
Polymer electrolyte membrane fuel cells need initial conditioning, activation or break-in the first time they are operated after being assembled. The initial conditioning procedure proposed and investigated in this paper consists of temperature and potential cycling. Temperature cycling is a new approach for the conditioning, and the idea is to rapidly cool a running cell at some point to allow the membrane to equilibrate with condensed water, which should result in higher intake of water within the membrane. The results show that proposed procedure is better or at least comparable to some conventional procedures for the initial conditioning. The MEAs reached their maximum performance quickly, within an hour, and performance was better than that obtained without temperature cycling.
\end{abstract}

Keywords: PEM fuel cells; conditioning; break-in; potential cycling; temperature cycling

\section{Introduction}

It is well known that the Polymer Electrolyte Membrane (PEM) fuel cells need initial conditioning, activation or break-in the first time they are operated after being assembled. ${ }^{1}$ During this period the performance of the fuel cell gradually increases until it reaches its final value. Depending on the membrane electrode assembly (MEA) and the break-in procedure, this process can take hours or even days to complete. So, choosing the right break-in procedure can save a lot of time as well as hydrogen. Despite this, little attention has been given to this topic and there are very few papers dealing with this matter. As a consequence, there is a general lack of understanding of the fundamentals going on within the MEA during the break-in process and there are more hypotheses than facts. ${ }^{1}$ Several conditioning protocols have been applied, patented and/or proposed, including both on-line methods, such as current control, potential control, short-circuiting and hydrogen pumping, as well as off-line methods like MEA steaming. ${ }^{1,2,3}$ There were even attempts to standardize the process but the choice of break-in procedure still lies with the practitioner. ${ }^{4}$ In general, it is accepted that high temperatures and high humidities coupled with high currents and/or load cycling are beneficial for the successful initial conditioning. ${ }^{2}$
While the exact mechanism of initial conditioning is not completely understood generally it is assumed that during the conditioning process the polymer membrane, as well as the polymer in the catalyst layer, gets humidified, and the number of active catalyst sites increases, thus improving the performance of the cell. Also, it is believed that during this period, the number of proton conducting channels increases.

The procedure proposed in this paper consists of both temperature and potential cycling. While the potential cycling is widely accepted to accelerate the initial conditioning, the temperature cycling is a novel approach. The idea is that at some point during the initial conditioning a fuel cell is rapidly cooled down, well below the dew point temperature of the incoming reactant gases. The reasoning behind this proposed procedure is that cycling to low voltages/high currents results in more water being produced, while cooling down the cell below the dew point allows water vapor to condense inside the fuel cell. It is well known that a membrane equilibrated with liquid water can take in more water molecules per sulfonic acid group $(\lambda=22)$ than the same membrane equilibrated with water vapor in saturated gas $(\lambda$ $=14)$. This phenomenon is called Schroeder's paradox. ${ }^{5}$

While the idea of controlling the cell temperature is not entirely new, to the best of our knowledge, no one has 
so far reported cycling of the cell's temperature with the running cell as a part of the initial conditioning protocol. Fumio, et al., reported dropping the temperature of a fuel cell as a part of the conditioning protocol but only after the cell was stopped and purged with dry gases. ${ }^{6}$ Similarly, Debe reported cooling the cell down to room temperature after being stopped and injecting liquid water in both compartments. ${ }^{7}$ There have also been attempts to over-saturate the incoming gases. Qi and Kaufman reported that saturating air and hydrogen at 90 and $95{ }^{\circ} \mathrm{C}$ dew points respectively, while keeping the cell temperature at $75{ }^{\circ} \mathrm{C}$, resulted in a short break-in period. ${ }^{8}$ The drawback is that at such humidification temperatures water vapor saturation pressures are very high, and therefore high reactants pressure, as well as high flows of the reactants, are needed (stoichiometries of 20 at $1 \mathrm{~A} / \mathrm{cm}^{2}$ were used in their experiments).

Sudden rapid cooling of a running cell creates oversaturated conditions, causing condensation throughout the cell, including in the catalyst layer. Liquid water in the catalyst layer remains in an intimate contact with the polymer, thus facilitating polymer equilibration with liquid water. This situation is much better than a case when oversaturated gases flow through the flow channels, because in that case water condenses mainly in the flow field channels.

\section{Experimental}

The tested MEAs were commercially available 12EW MEA produced by BASF with Nafion 112 membranes and $50 \mathrm{~cm}^{2}$ active area. The cells were assembled in a coflow configuration with single serpentine flow field on the anode and quadruple serpentine on the cathode side. Before the tests, the assembled cells were shortly purged with dry nitrogen to remove any residual air in the anode compartment. Pure hydrogen and synthetic air were used as the reactant gases, each with relative humidity ( $\mathrm{RH})$ of $100 \%$ at $65{ }^{\circ} \mathrm{C}$ in all experiments. Back pressures were also constant in all experiments, 1.2 and 1.5 bar absolute on the anode and the cathode respectively.

The experiments were conducted with the Teledyne Medusa RD fuel cell test station with built-in electrochemical impedance spectroscopy (Scribner \& Assoc.), and data acquisition system (software: Scribner \& Assoc.; hardware: National Instruments).

Polarization curves were recorded every hour with $50 \mathrm{~mA} / \mathrm{cm}^{2}$ steps and four seconds per point at the cell temperature of $65{ }^{\circ} \mathrm{C}$ and $100 \%(\mathrm{RH})$ of both reactants. Polarization curves scans were performed in constant stoichiometry mode with stoichiometry of 1.4 on the anode and 2.3 on the cathode.

In the proposed procedure the cell was cycled between $65^{\circ} \mathrm{C}$ and $50{ }^{\circ} \mathrm{C}$ with the rest time at each temperature of 20 minutes, while the temperature and relative hu- midity of the incoming reactant gases were kept constant at $65{ }^{\circ} \mathrm{C}$ and $100 \%$ respectively. The cell was first operated at constant voltage of $0.6 \mathrm{~V}$ and temperature of $65^{\circ} \mathrm{C}$. After approximately 20 minutes the load was switched to $0.8 \mathrm{~V}$ while the cell was forcibly cooled down to $50{ }^{\circ} \mathrm{C}$ with the help of a fan. At this temperature the water saturation pressure is about half of that at $65^{\circ} \mathrm{C}$, and since the gases inside the cell quickly equilibrate with the cell's temperature, significant condensation occurs within the cell. The cell was kept at these conditions for about $20 \mathrm{mi}-$ nutes, when the load was switched back to $0.6 \mathrm{~V}$ and the cell heated again to $65^{\circ} \mathrm{C}$. This was done repeatedly. The reactants' flow rate was set as constant at 0.45 Standard Liters Per Minute (SLPM) on the anode and 1.72 SLPM on the cathode. This corresponds to stoichiometries of 1.4 and 2.3 on the anode and the cathode respectively at 900 $\mathrm{mA} / \mathrm{cm}^{2}$, which is the expected value of generated current at $0.6 \mathrm{~V}$ at the end of the break-in process. The constant high flow was chosen to avoid excessive flooding and ensure effective removal of the condensed water from the flow field channels while operating at the high voltage/low temperature regime.

\section{Results and Discussion}

Figure 1 shows current density evolution over time. Polarization curves were scanned after the $3^{\text {rd }}$ cycle $(\sim 60$ $\mathrm{min})$ and after each two subsequent cycles ( $40 \mathrm{~min})$. The fuel cell almost reached its maximum performance after only $\sim 1$ hour. There was practically negligible improvement in the performance recorded after second scan $(<2 \%$ improvement at $0.6 \mathrm{~V}$ after the $5^{\text {th }}$ cycle) while no further improvement was noticed for the subsequent scans.

It should be noted that due to the problems with flooding, all the scans exhibited little weaker performance at lower current densities $\left(<200 \mathrm{~mA} / \mathrm{cm}^{2}\right)$. However, this is temporary reversible condition which eventually disappeared. The proposed protocol was done on two MEAs to ensure the repeatability of the results.

It is interesting that in the literature, the time needed to break-in an MEA, which are usually in-house built, varies from several hours up to more than one day, depending on the applied break-in procedure. In our case commercial MEAs from a renowned manufacturer were used and the break-in times were much shorter. The proposed procedure was compared with three other procedures. The first one was according to the recommendation of the MEA producer, and it was to keep the cell at $0.6 \mathrm{~V}$ and 65 ${ }^{\circ} \mathrm{C}$ with the stoichiometries of 1.4 and 2.3 on anode and cathode respectively and $100 \%$ RH. The second one was with the same parameters but this time the voltage was kept at $0.7 \mathrm{~V}$ in order to see whether it is possible to break-in a cell at lower currents, thus saving on the consumed fuel. The third one was to use potential cycling between 0.7 and $0.5 \mathrm{~V}$ with the frequency of 60 seconds with 


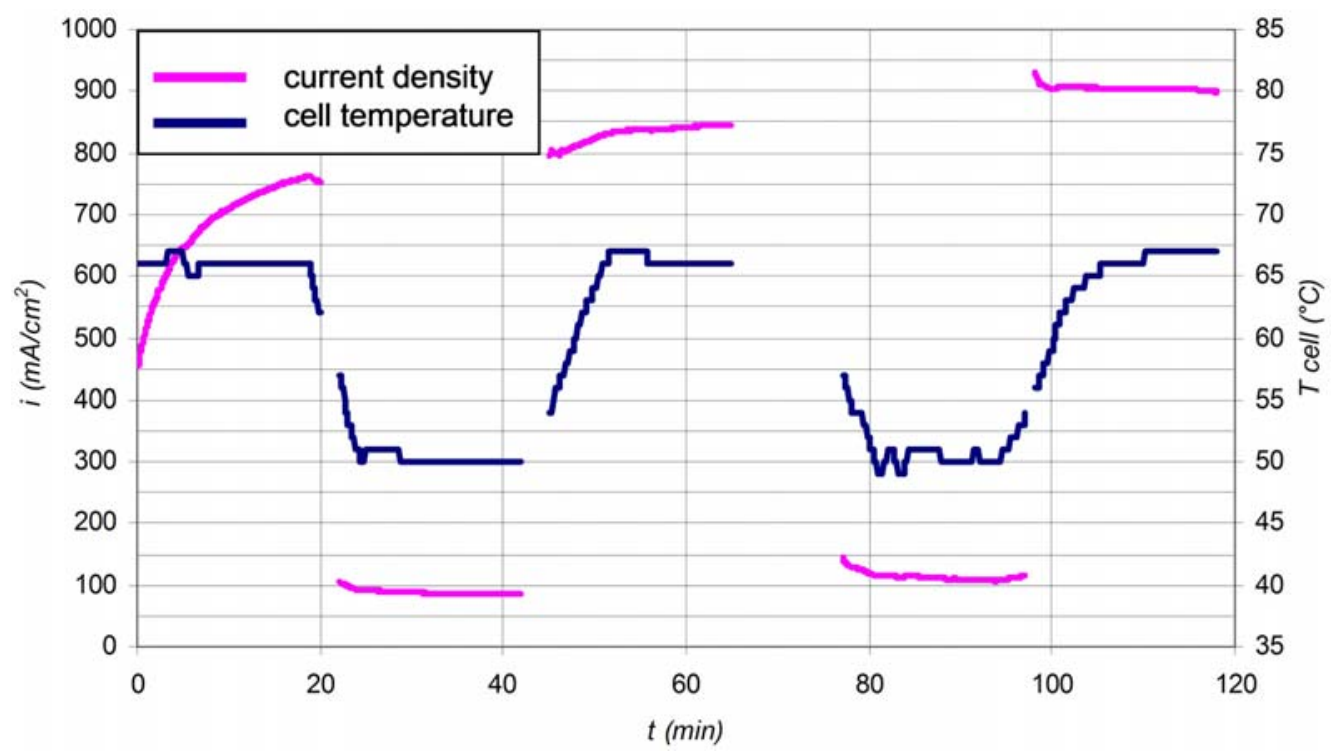

Fig. 1. Initial conditioning by temperature and potential cycling

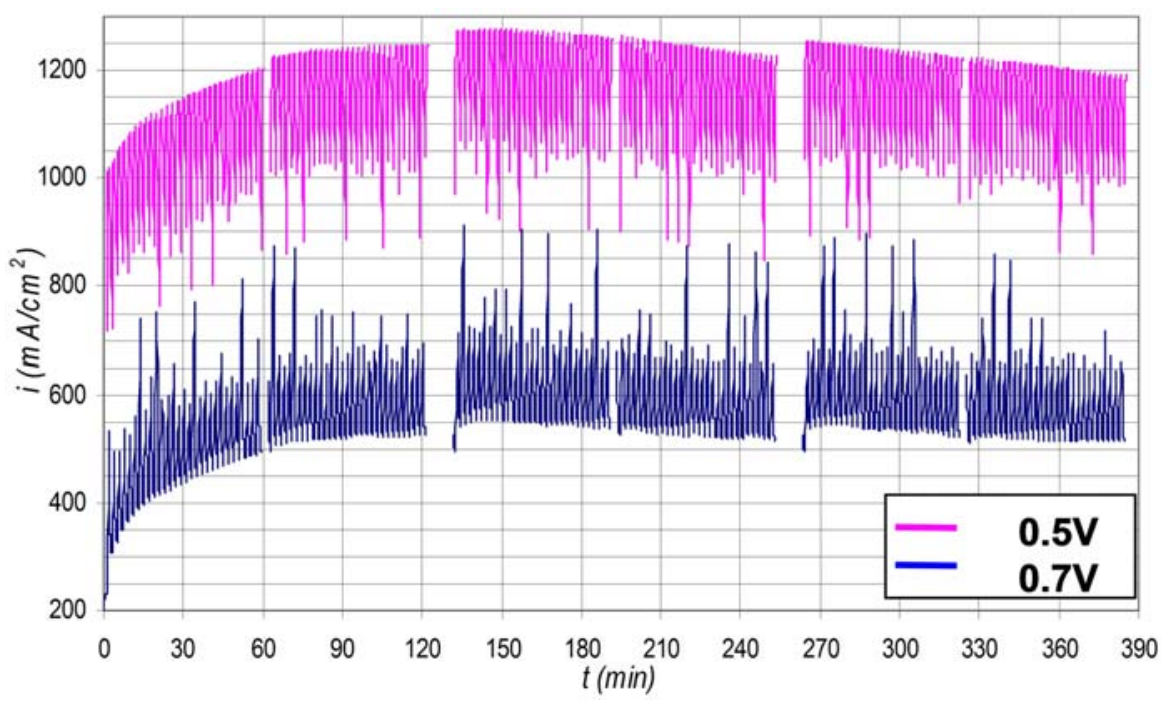

Fig. 2. Initial conditioning by potential cycling

other parameters same as in previous procedures. Current density evolution over time at both voltages is shown in Fig. 2. Potential cycling is known to accelerate initial conditioning while increasing the frequency of cycling reduces the activation time even more. ${ }^{2}$

The first procedure (constant voltage of $0.6 \mathrm{~V}$ ) reached its maximum performance after four hours but with little improvements after the first hour; only about $5 \%$ at $0.6 \mathrm{~V}$, Fig 3. Still the final performance is somewhat weaker at higher current densities compared to the procedure with temperature and potential cycling. The second procedure (constant voltage of $0.7 \mathrm{~V}$ ) reached its maximum after about three hours, but the final performance was consi- derably worse compared to the proposed procedure. Thus, it was shown that high current densities are mandatory for successful MEA conditioning.

Potential cycling gave better results than previous two procedures as not only it gave better overall performance, but the break-in procedure was completed in approximately two hours. The performance was more or less the same as with proposed procedure of temperature and potential cycling, albeit at somewhat longer time. Also, it is important to remember that frequent cycling has negative impact on the cell lifetime. Comparison of the final polarization curves for the different initial conditioning procedures is given in Fig 4. 


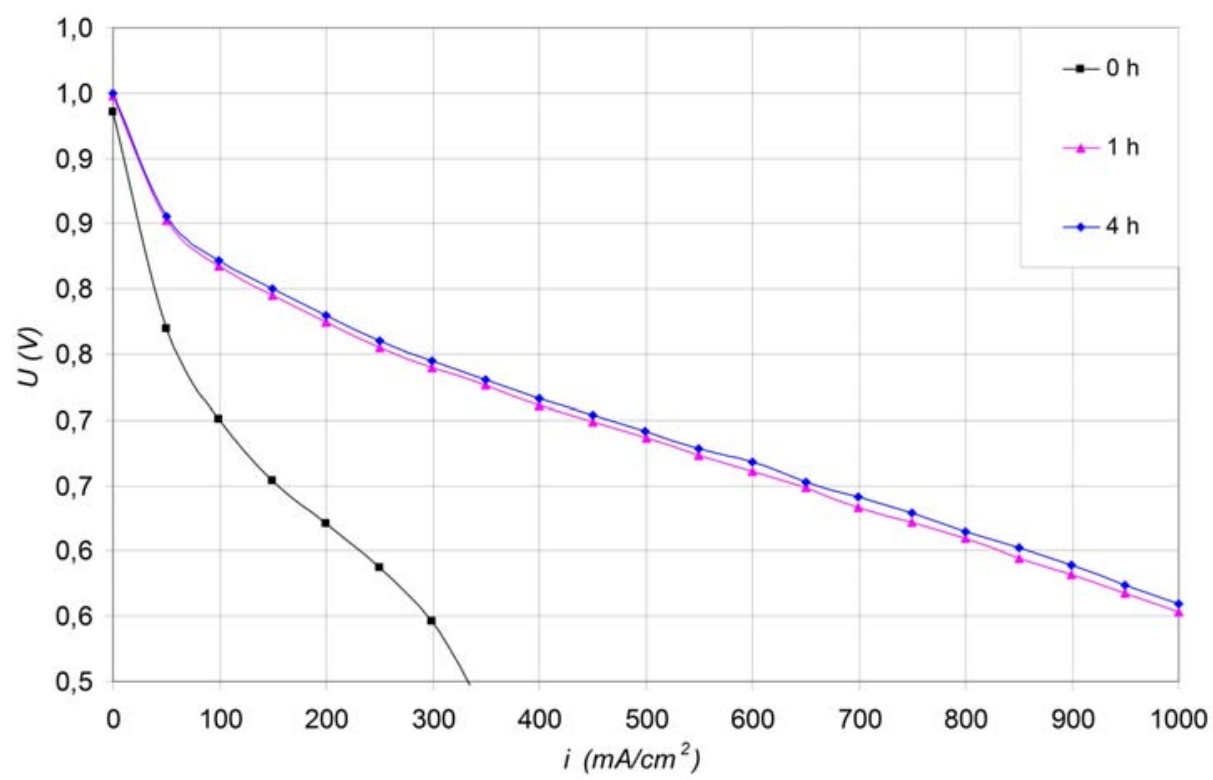

Fig. 3. Polarization curve change for the constant voltage break-in

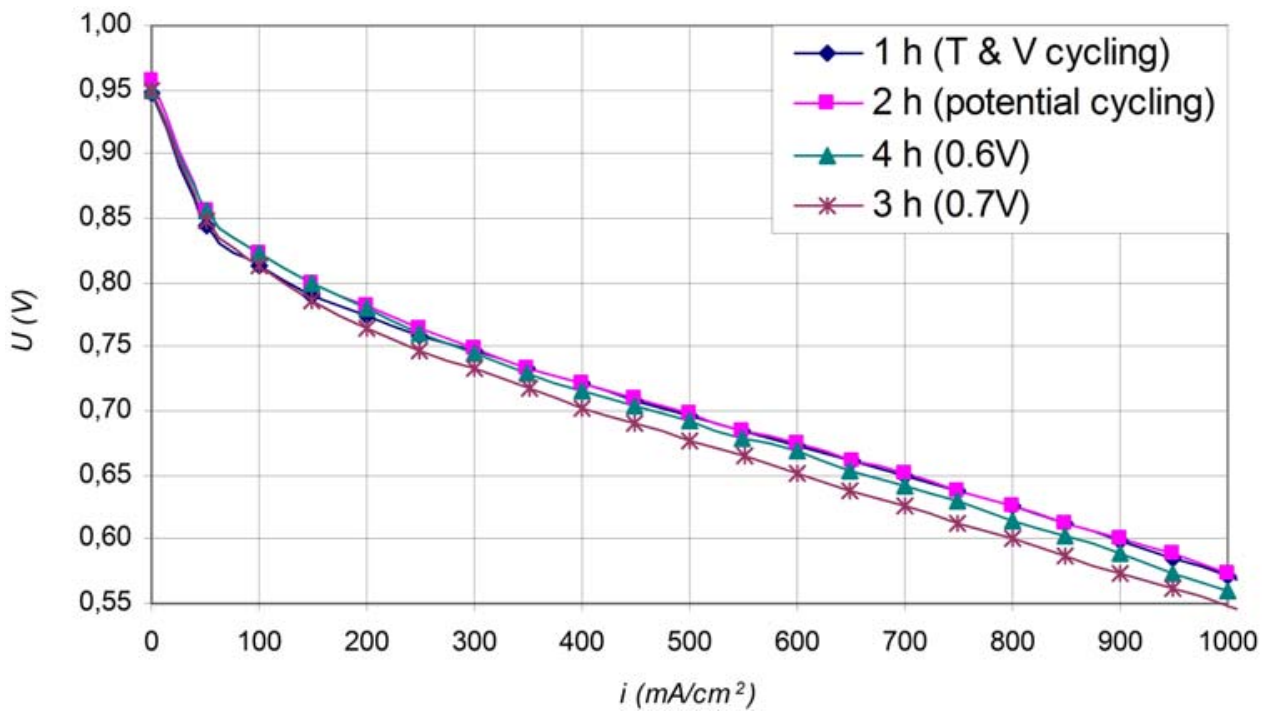

Fig. 4. Final polarization curves after different initial conditioning protocols

As it can be seen, the temperature and potential cycling procedure proved to be an excellent choice for the initial conditioning as it gave better performance than the procedure recommended by the producer itself, while it replicated the performance of another popular approach consisting of frequent cycling but in a shorter time.

\section{Conclusion}

PEM fuel cells need initial conditioning in order to reach the best performance. A new approach of temperature and potential cycling is applied and the results show that cooling of a running cell helps the conditioning process as the obtained results are better, or at least comparable to some conventional break-in protocols. It is believed that condensation within the cell during the break-in process is beneficial for the membrane water uptake which should result in better cell performance. Our findings somewhat replicate the findings of Qi and Kaufmann ${ }^{8}$ though at lower temperatures, pressures and reactants' flows. The exact temperatures, voltages and cycling frequencies in the presented procedure were chosen arbitrarily based on our experience and practical reasons. Our goal was to see if this simple idea works and the right choice of the aforementioned parameters is another topic 
worth of further research. Also, the protocol should be tested on the different MEAs, as with the MEAs that need longer conditioning than the ones we used in our experiments the differences between the different protocols should be even more obvious.

\section{References}

1. X. Z. Yuan, S. Zhang, J. C. Sun, H. Wang, J. Power Sources, 2011, 196, 9097-9106. http://dx.doi.org/10.1016/j.jpowsour.2011.06.098

2. X. Z. Yuan, J. C. Sun, H. Wang, H. Li, J. Power Sources, 2012, 205, 340-344. http://dx.doi.org/10.1016/j.jpowsour.2012.01.039

3. Z. Xu, Z. Qi, C. He, A. Kaufman, J. Power Sources, 2006, 156, 315-320.

http://dx.doi.org/10.1016/j.jpowsour.2005.05.072
4. USFCC single cell test protocol, http://www.fchea.org/core/ import/PDFs/Technical\%20Resources/MatComp\%20Single \%20Cell\%20Test\%20Protocol\%2005-014RevB.2\%20071 306.pdf (last accessed 16.10.2013).

5. S. Gottesfeld, T. A. Zawodzinski, in R. C. Alkire, H. Gerischer, D. M. Kolb, C. W. Tobias (Eds.), Advances in Electrochemical Science and Engineering, Vol. 5, Wiley-VCH, New York, 1997 pp. 195-301. http://dx.doi.org/10.1002/9783527616794.ch4

6. K. Fumio, M. Naoya, S. Ryoichi, Fuel cell conditioning system and related method, European Patent 05004688.7, 2005.

7. M. K. Debe, Advanced cathode catalyst and supports for PEM fuel cells, DOE Hydrogen Program 2010 Annual Merit Review Proceedings, http://www.hydrogen.energy.gov/pdfs /review10/fc001_debe_2010_o_web.pdf June 8, 2010, (last accessed 16. 10. 2013).

8. Z. Qi, A. Kaufman, J. Power Sources, 2002, 111, 181-184. http://dx.doi.org/10.1016/S0378-7753(02)00273-2

\section{Povzetek}

Gorivne celice s polimernimi elektrolitskimi membranami (PEM) je potrebno pred prvo uporabo podvreči postopku začetne aktivacije. Predlagani in preučevani postopek aktivacije je sestavljen iz temperaturnega in napetostnega ciklanja. Začetna aktivacija gorivne celice PEM s pomočjo temperaturnega ciklanja predstavlja nov pristop. Bistvena zamisel predlaganega postopka je $\mathrm{v}$ hitri ohladitvi obratujoče gorivne celice v določeni delavni točki. Le-ta povzroči kondenziranje vode znotraj celice, $\mathrm{s}$ čemer je omogočen večji vnos vode $\mathrm{v}$ membrano in pripomore k vzpostavitvi ustreznega ravnotežja vlažnosti le-te. Rezultati kažejo, da je predlagani pristop boljši oziroma vsaj primerljiv z nekaterimi že uveljavljenimi postopki začetne aktivacije. Maksimalna učinkovitost gorivne celice PEM je s takšnim pristopom dosežena $\mathrm{v}$ roku ene ure in je višja kot pri postopkih brez temperaturnega ciklanja. 